\title{
Human exposure to potential rabies virus transmitters in Olinda, State of Pernambuco, between 2002 and 2006
}

\author{
Exposição humana a potenciais transmissores do vírus rábico em Olinda, \\ Estado de Pernambuco, entre 2002 e 2006
}

\author{
Filipe Dantas-Torres ${ }^{1}$ and Edmilson Ferreira de Oliveira-Filho ${ }^{2}$
}

\begin{abstract}
The aim of the present study was to evaluate the data on human exposure to potential rabies virus transmitters in Olinda, State of Pernambuco, Brazil. Data from 7,062 patients who underwent antirabies prophylactic treatment in Olinda between 2002 and 2006 were analyzed. As expected, dogs and cats were involved in most of the cases; i.e. 82.3 and 16.3\%, respectively. Attacks by nonbuman primates, bats and other species (unspecified) were also reported. Among the 7,062 patients who underwent antirabies treatment, 582 patients abandoned the treatment, either by indication from the health unit (195) or by their own decision (387). In conclusion, this study bas indicated that prophylaxis for human rabies in this urban area will require a multifaceted approach, including health education, post-exposure prophylaxis, systematic vaccination for dogs and cats, and possibly selective control over wild animals such as hematophagous bats.
\end{abstract}

Key-words: Rabies. Epidemiology. Prophylaxis. Control.

\section{RESUMO}

O objetivo deste estudo foi avaliar os dados sobre a exposição humana a potenciais transmissores do vírus rábico em Olinda, Pernambuco, Brasil. Foram analisados dados de 7.062 pacientes submetidos ao tratamento anti-rábico em Olinda entre 2002 e 2006. Como esperado, cães e gatos estiveram envolvidos na maioria dos casos; isto é, 82,3 e 16,3\%, respectivamente. Ataques por primatas não-bumanos, morcegos e outras espécies (não especificadas) também foram relatadas. Dos 7.062 pacientes submetidos ao tratamento anti-rábico, 582 abandonaram o tratamento, seja por indicação da unidade de saúde (195) ou por decisão própria (387). Concluindo, esse estudo indica que a profilaxia da raiva humana nessa área urbana irá requer uma abordagem multifacetada, incluindo educação em saúde, profilaxia pós-exposição, vacinação sistemática de cães e gatos e, eventualmente, o controle seletivo de animais silvestres, tais como morcegos hematófagos.

Palavras-chaves: Raiva. Epidemiologia. Profilaxia. Controle.

It is well known that human-induced climate change and landuse activities might influence the emergence or reemergence of many communicable diseases, such as malaria, leishmaniasis, trypanosomiasis and dengue ${ }^{14}{ }^{17}$. Scientific advances such as vaccine development can also lead to remarkable changes in the epidemiology of certain infectious diseases, as is the case with human rabies. The availability of an effective vaccine and great efforts by public health authorities worldwide have made it possible to bring dog and cat-transmitted human rabies under control in several countries, and even to eradicate it. On the other hand, human pressure on the environment and close contact between humans and wild animals, which has become increasingly frequent, are causing a dramatic change in the epidemiology of human rabies in most areas where the disease remains endemic ${ }^{3713212223}$.

Recent analyses of the epidemiological situation of rabies in the Americas have revealed that the incidence of canine and human rabies has undergone a significant reduction, particularly over the last two decades ${ }^{316} 22$. The incidence of human rabies cases in this region dropped from 216 in 1993 to 39 in 2002. Likewise, while 6,716 cases of rabies in dogs were reported in 1993, 1,311 were recorded in $2002^{3}$. An analysis of the trend in rabies cases from 1982 to 2003 revealed a reduction in the number of human cases from 355 to $35^{22}$. The success of human rabies control can be attributed to two main strategies: vaccination of dogs and cats and human rabies post-exposure prophylaxis ${ }^{322}$. Systematic rabies

1. Centro de Pesquisas Aggeu Magalhães, Fundação Oswaldo Cruz, Recife, PE. 2. Universidade Federal Rural de Pernambuco, Recife, PE.

Address to: Dr. Filipe Dantas-Torres. CPqAM/FIOCRUZ. Av. Moraes Rego s/n, Caixa Postal 7472, 50670-420 Recife, PE, Brasil.

Telefax: 5581 3453-2449

e-mail: fdt@cpqam.fiocruz.br

Recebido para publicação em: 03/09/2007

Aceito em 05/11/2007 
vaccination campaigns have been carried out every year, or even every six months, in most of the countries where human rabies is endemic. Out of approximately one million people exposed to potential rabies virus transmitters who seek care from the health system every year, around 30\% receive prophylactic treatment against rabies ${ }^{3}$.

Following this trend, the number of human rabies cases transmitted by dogs in Brazil underwent a notable reduction over the last two decades. Conversely, cases of human rabies transmitted by wild animals, e.g. hematophagous bats and marmosets, has undergone a relatively increase over recent years ${ }^{3720}$. In the State of Pernambuco, cases of human rabies are relatively rare nowadays, although cases of animal rabies have frequently been recorded $^{15}$. Cases of acts of aggression by bats on humans in the municipality of Recife have recently been reported, thus indicating the risk of occurrences of human rabies transmitted by bats in Pernambuco. The aim of the present study was to evaluate the data on human exposure to potential rabies virus transmitters in the municipality of Olinda, where cases of acts of aggression by bats on pet dogs have recently been reported 5 .

\section{MATERIAL AND METHODS}

Study area. This study was carried out in the municipality of Olinda ( $\left.8^{\circ} 00^{\prime} 48^{\prime \prime} 34^{\circ} 50^{\prime} 42^{\prime \prime} \mathrm{W}\right)$, which is located in the metropolitan region of Recife, on the coast of the State of Pernambuco, in northeastern Brazil (Figure 1). Olinda has a population of approximately 368,000 inhabitants, unequally spread over a territory of approximately 40.8 square kilometers. In 1982, the historic central area of Olinda was declared by the United Nations Educational, Scientific and Cultural Organization (UNESCO) as Historical and Cultural Heritage of Mankind. The city's climate is tropical, with a mean annual temperature of $27^{\circ} \mathrm{C}$, annual relative humidity of $80 \%$ and annual precipitation of between 1,000 and $2,000 \mathrm{~mm}$.
The municipality of Olinda has conducted systematic, sixmonthly mass rabies vaccination campaigns targeting dogs and cats. If at any time a case of animal rabies is recorded, focal vaccination of dogs and cats is carried out. Nowadays, cases of animal rabies are only rarely being reported.

Data source and procedures. Information on human rabies post-exposure prophylaxis in Olinda, from 2002 to 2006, was obtained from the National Disease Surveillance Data System (SINAN) of the Brazilian Ministry of Health. For this study, the following information was selected: type of aggression (locality, severity and circumstance); type of animal involved; patient's sex, age group and district of origin.

A thematic map depicting the spatial distribution of the antirabies treatment in Olinda throughout the study period was constructed using the TabWin software (DATASUS, Brazil), version 3.2 .

\section{RESULTS}

From 2002 to 2006, a total of 7,062 patients underwent antirabies prophylactic treatment in Olinda following exposure to a potential rabies virus vector. The animals involved in these cases included dogs, cats, nonhuman primates (e.g. marmosets) and bats. Dogs were responsible for 5,809 (82.3\%) cases of acts of aggression, followed by cats $(16.3 \%)$, nonhuman primates $(0.4 \%)$, bats $(0.2 \%)$, and others $(0.3 \%)$. Information on the animals involved was missing or unknown in $36(0.5 \%)$ cases of aggression (Table 1).

There were 2,734 acts of aggression on lower limbs, 1,446 on upper limbs, 593 on the trunk, and 620 on the head/neck. In 5,332 cases the lesions were deep and in 5,037 cases the lesions were multiple. Regarding the circumstances in which the aggression occurred, 5,696 patients were exposed during leisure time,

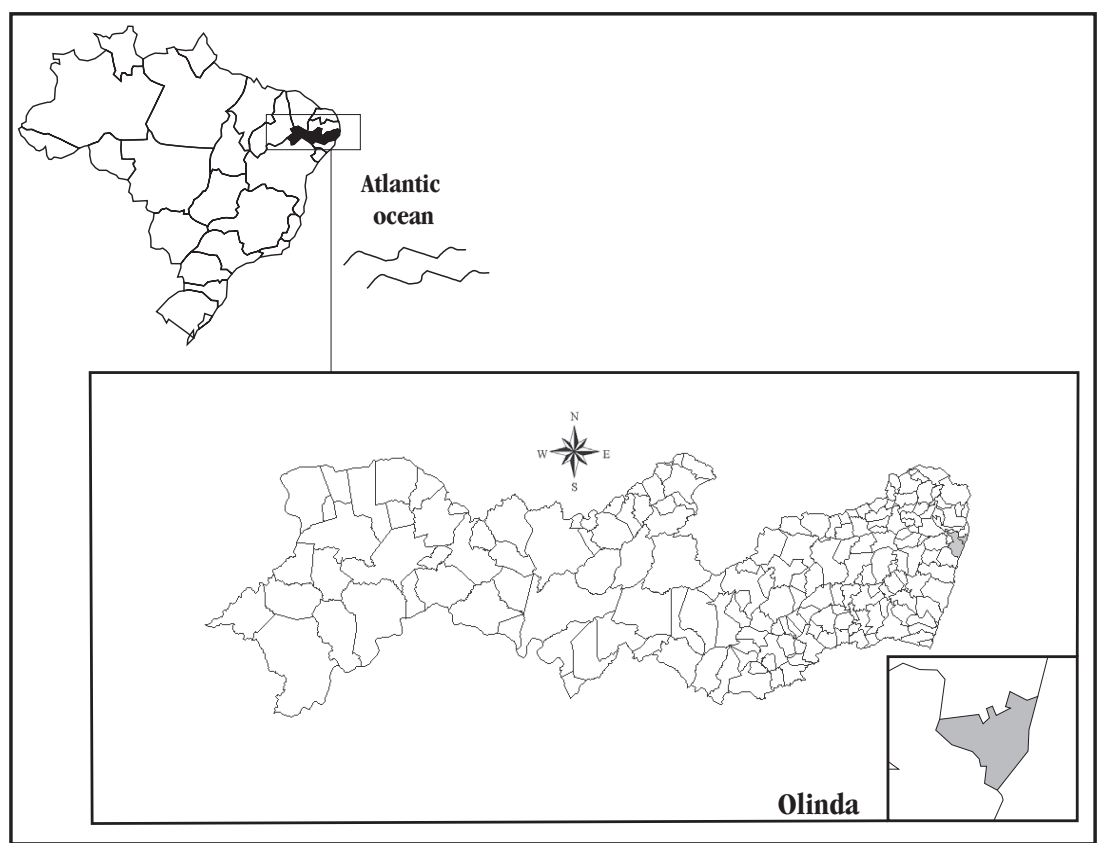

Figure 1 - Location of the study area in the State of Pernambuco, northeastern, Brazil. 
Table 1 - Human exposure to potential rabies virus transmitters in Olinda, State of Pernambuco, Brazil, from 2002 to 2006.

\begin{tabular}{lrr}
\hline & \multicolumn{2}{c}{ Individuals exposed } \\
\cline { 2 - 3 } Animal type & $\mathrm{n}^{0}$ & $\%$ \\
\hline Dogs & 5,809 & 82.3 \\
Cats & 1,149 & 16.3 \\
Nonhuman primates & 30 & 0.4 \\
Bats & 16 & 0.2 \\
Others & 22 & 0.3 \\
Unknown/missing data & 36 & 0.5 \\
\hline Total & 7,062 & 100 \\
\hline
\end{tabular}

553 were attacked by an aggressive animal, and 119 by an animal with changed behavior. Information on the circumstances in which the aggression occurred was lacking in 694 cases.

The ages of the individuals exposed to potential rabies virus transmitters ranged widely: from $<1$ to $>80$ years old. Children aged 5-9 years were proportionally more affected than was any other age group (Table 2). More patients were males $(3,643)$, although the difference between males and females was negligible.

Out of the 7,062 individuals who underwent rabies post-exposure prophylaxis, 582 abandoned the treatment, either by indication from the health unit (195) or by their own decision (387).
Table 2 - Human exposure to potential rabies virus transmitters in Olinda, State of Pernambuco, Brazil, from 2002 to 2006.

\begin{tabular}{lrc}
\hline Age group & Number & Percentage \\
\hline$<1$ & 41 & 0.6 \\
$1-4$ & 648 & 9.2 \\
$5-9$ & 1,200 & 17.0 \\
$10-14$ & 897 & 12.7 \\
$15-19$ & 522 & 7.4 \\
$20-29$ & 868 & 12.3 \\
$30-39$ & 682 & 9.7 \\
$40-49$ & 743 & 10.5 \\
$50-59$ & 653 & 9.2 \\
$60-69$ & 442 & 6.3 \\
$70-79$ & 261 & 3.7 \\
$\geq 80$ & 103 & 1.5 \\
Unknown/missing data & 2 & $<0.1$ \\
\hline Total & 7,062 & 100 \\
\hline
\end{tabular}

Regarding the district of origin, most individuals were from Rio Doce (836), Ouro Preto (731), Jardim Atlântico (482), Peixinhos (447), Águas Compridas (356) and Jardim Brasil (314). Together, these districts recorded $44.8 \%$ of the cases. The spatial and temporal distributions of acts of animal aggression recorded in Olinda during the study period are shown in Figure 2 and Figure 3, respectively.

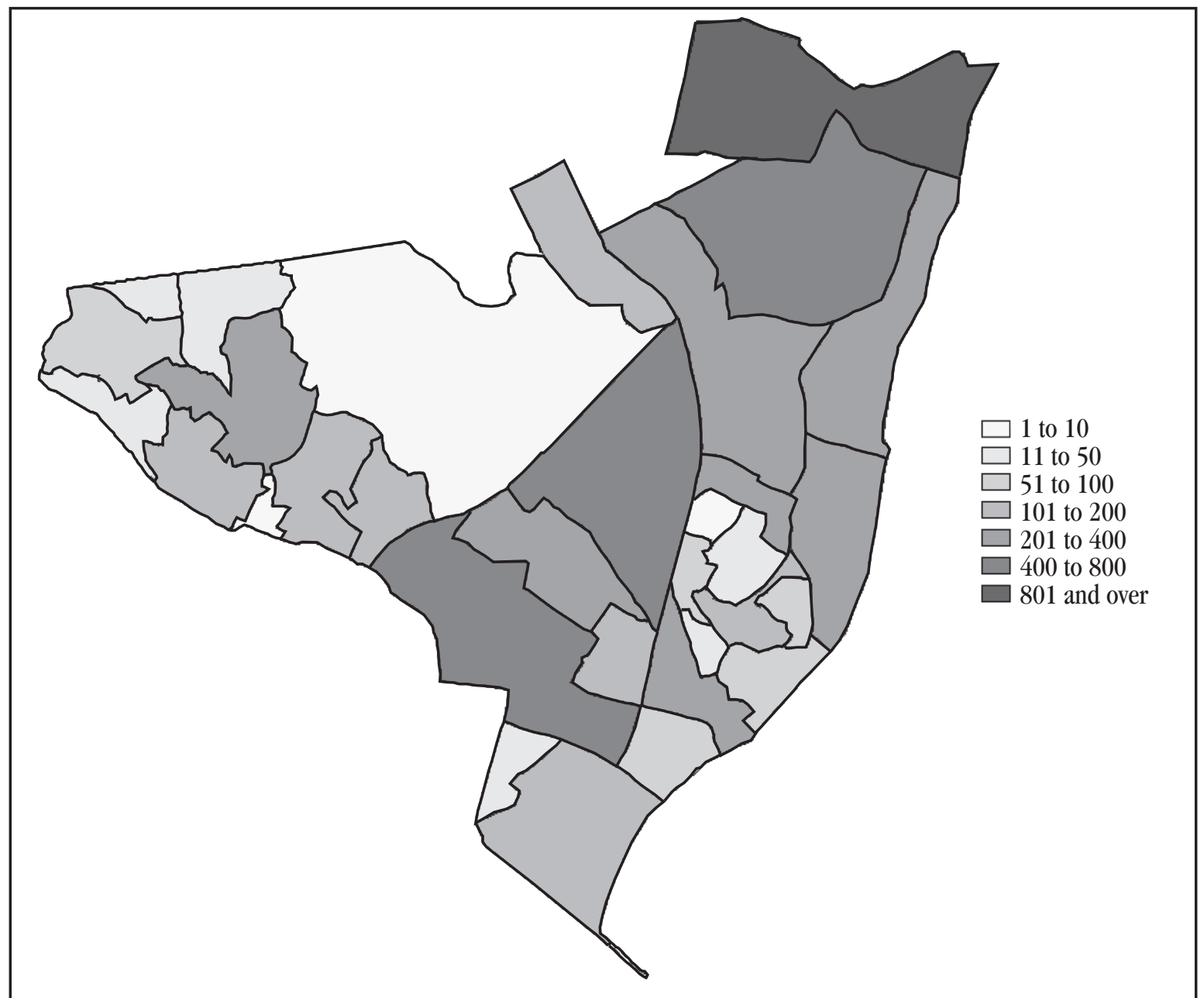

Figure 2 - Spatial distribution of cases of human exposure to potential rabies virus transmitters in Olinda, State of Pernambuco, Brazil, from 2002 to 2006. 


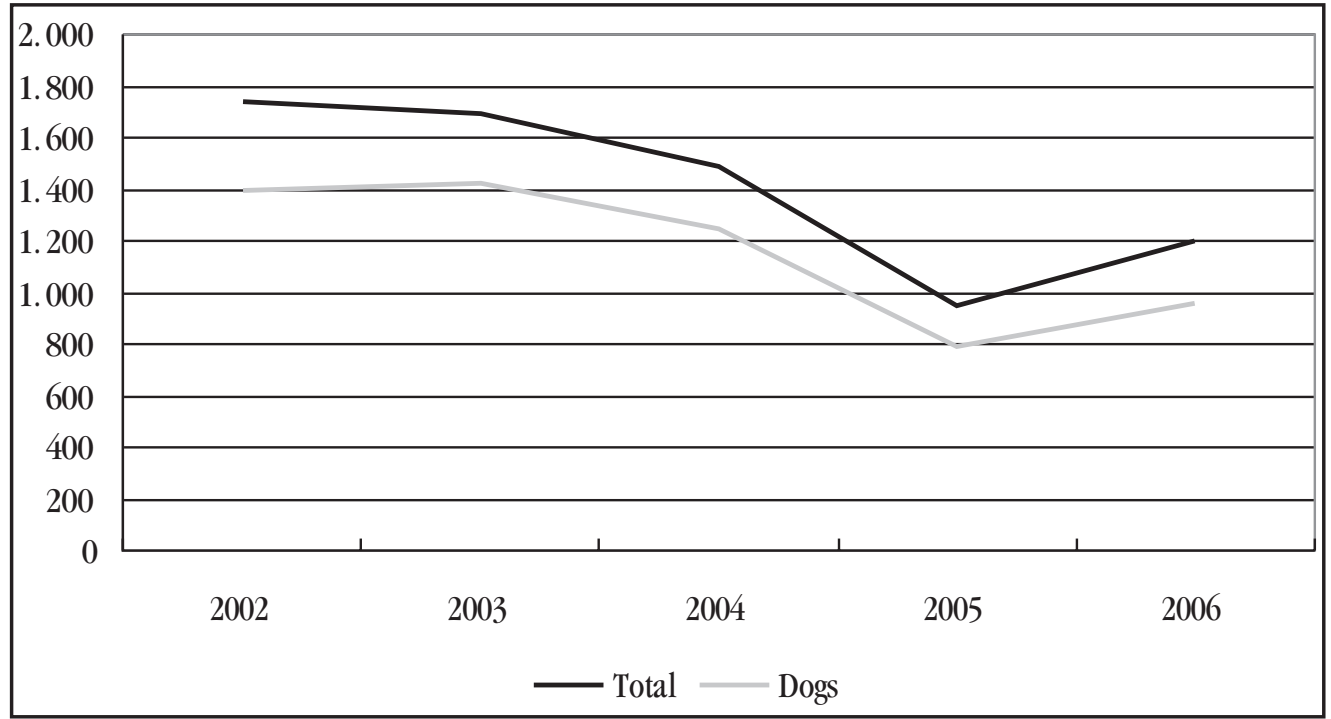

Figure 3 - Temporal distribution of cases of human exposure to potential rabies virus transmitters in Olinda, State of Pernambuco, Brazil, from 2002 to 2006.

\section{DISCUSSION}

Historically, dogs and cats have been implicated as the main transmitters of human rabies not only in Brazil, but also in most other countries where the disease is still occurring. Over the last two decades, the incidence of human rabies transmitted by wild animals like raccoons, skunks, foxes and bats has increased, particularly in Latin America, where hematophagous bats have surpassed dogs in relation to transmitting the rabies virus to humans 378132022 .

Bats are considered to be the natural reservoirs for the rabies virus ${ }^{62}$. There has been an increasing risk of human exposure to both hematophagous and non-hematophagous bats in the Americas ${ }^{34}$. Attacks of vampire bats on humans have been linked to factors such as gold mining, livestock movements and deforestation ${ }^{13}$. In outbreaks of human rabies transmitted by vampire bats in the Amazon region of Brazil and Peru, humanmade environmental modifications to bat habitats, (e.g. the transformation of wildlife areas into suburban areas), were noted as possible risk factors for the incidence of the disease ${ }^{3}$. A number of cases of human rabies transmitted by hematophagous bats have been reported in Brazil ${ }^{101120}$ and elsewhere ${ }^{1224}$. Acts of aggression by bats on dogs have also been reported. It is not rare to see vampire bats feeding on domestic animals, particularly dogs, in urban areas 5 . Since dogs are often close to people, vampire bat attacks on these animals should be taken as an indicator of the risk of possible attacks on humans. Indeed, the control of rabies in wild animal species, particularly bats, is obviously more complex than in domestic animals. Wild animals have different behaviors and live in a wide, diverse range of wild environments. Moreover, wild species are often listed as protected animals ${ }^{23}$.

Nonhuman primates are potential sources of rabies virus. Marmosets (Callithrix jacchus) have been associated with human rabies transmission in Brazil ${ }^{27}$. It is very likely that the proximity of marmosets to urban settlements and the common practice of keeping them as pets are major contributory factors towards the risk of human exposure to these potential rabies virus transmitters. This practice is illegal in Brazil and should be strongly discouraged.

Studies on human rabies post-exposure prophylaxis have revealed that the $\mathrm{WHO}$ recommendations (for more details, $\mathrm{see}^{25}$ ) are frequently neglected or ignored ${ }^{16} 1819$. This can increase the risk of rabies considerably and result in unfavorable outcomes. Adherence to the WHO-recommended guidelines ensures protection against rabies $^{25}$. Analyzing the cases of human rabies reported in the United States from 1980 to 1998, researchers at the Centers for Disease Control and Prevention observed that none of the 32 patients received post-exposure prophylaxis before the onset of clinical disease ${ }^{16}$. This highlights the importance of rapid post-exposure prophylaxis for individuals exposed to potential rabies virus transmitters.

The increasing risk of human rabies transmitted by wild animals is an emerging challenge to public health worldwide. This situation is likely to require a multifaceted strategy for disease control and prevention, particularly in areas where the risk of human rabies transmitted by wild animals is high. This integrated approach should include much more than human rabies post-exposure prophylaxis, dog population management and mass immunization.

Community awareness constitutes one of the biggest deficiencies in most rabies control programs. Information on control and prevention measures regarding rabies is generally lacking or limited. In certain areas, the control of rabies in wildlife is also warranted and this includes population management and mass immunization of the principal wildlife hosts ${ }^{5}$. Human pre-exposure prophylaxis should be considered, especially for people at high risk of exposure to potential rabies virus transmitters, e.g. individuals working in rabies diagnostic or research laboratories, wildlife and animal control officers, veterinarians, animal handlers and cave explorers. Pre-exposure prophylaxis should also possibly be offered to individuals living in or traveling to high-risk areas ${ }^{25}$. 
The prophylactic procedures against rabies for children and adults that have been adopted in Olinda follow the WHO recommendations ${ }^{25}$. A total of 5,909 vaccine doses and 331 rabies immunoglobulin injections were given to people exposed to potential rabies virus transmitters in Olinda, from 2002 to 2006 (results not shown). Considering the whole study period, cases of human exposure to potential rabies virus transmitters were notified in all districts of Olinda. The temporal distribution of the cases showed a slight increase in 2005 after a decreasing trend that started in 2002 (Figure 3). The possible reasons for this temporal distribution pattern should be the subject of future studies. Likewise, it is important to further investigate why so many patients have abandoned treatment in Olinda. Studies to address these questions are highly recommended.

The local public health authorities in Olinda should continue to focus their efforts on the systematic vaccination of dogs and cats, prompt and complete human rabies post-exposure prophylaxis, responsible animal ownership, and stray dog and cat population management. Studies on the antigenic rabies virus variants circulating among dogs, cats and other animals, particularly bats, should be encouraged, in order to improve our understanding of the dynamic of rabies virus transmission in Olinda. Likewise, the localization and monitoring of all hematophagous bat populations living in this municipality are warranted.

\section{ACKNOWLEDGEMENTS}

To the Municipal Health Department of Olinda for kindly providing the data used in this study and to Alessandra Ribeiro de Albuquerque for English revision. Dantas-Torres is the recipient of a PhD studentship from the Coordenação de Aperfeiçoamento de Pessoal de Nível Superior (CAPES).

\section{REFERENCES}

1. Batista-da-Costa M, Bonito RF, Nishioka SA. An outbreak of vampire bat bite in a Brazilian village. Tropical Medicine and Parasitology 44:219-220, 1993.

2. Batista-Morais N, Neilson-Rolim B, Matos-Chaves HH, Brito-Neto J, Maria-da-Silva L. Rabies in tamarins (Callithrix jacchus) in the State of Ceará, Brazil, a distinct viral variant? Memórias do Instituto Oswaldo Cruz 95:609-610, 2000.

3. Belotto A, Leanes LF, Schneider MC, Tamayo H, Correa E. Overview of rabies in the Americas. Virus Research 111:5-12, 2005.

4. Brazuna JC, Teixeira MA, van Onselen VJ. An epidemiological description of human-hazardous incidents caused by nonhematophagous bats in Brazil, 20022003. Preventive Veterinary Medicine 77:137-144, 2006.

5. Dantas-Torres F, Valenca C, Andrade Filho GV. First record of Desmodus rotundus in urban area from the city of Olinda, Pernambuco, Northeastern Brazil: a case report. Revista do Instituto de Medicina Tropical de Sao Paulo 47:107-108, 2005 .
6. Dimitrov DT, Hallam TG, Rupprecht CE, Turmelle AS, McCracken GF. Integrative models of bat rabies immunology, epizootiology and disease demography. Journal of Theoretical Biology 245:498-509, 2007.

7. Favoretto SR, Mattos CC, Morais NB, Araújo FAA, Mattos CA. Rabies in marmosets (Callithrix jacchus), Ceará, Brazil. Emerging Infectious Diseases 7:1062-1065, 2001.

8. Favoretto SR, Mattos CC, Morais NB, Carrieri ML, Rolim BN, Silva LM, Rupprecht CE, Durigon EL, Mattos CA. Rabies virus maintained by dogs in humans and terrestrial wildlife, Ceará State, Brazil. Emerging Infectious Diseases 12:1978-1981, 2006.

9. Garcia RCM, Vasconcellos SA, Sakamoto SM, Lopez AC. Análise de tratamento anti-rábico humano pós-exposição em região da Grande São Paulo, Brasil. Revista Saúde Pública 33:295-301, 1999.

10. Gonçalves MA, Sá-Neto RJ, Brazil TK. Outbreak of aggressions and transmission of rabies in human beings by vampire bats in northeastern Brazil. Revista da Sociedade Brasileira de Medicina Tropical 35:461-464, 2002.

11. Gupta R. Recent outbreak of rabies infections in Brazil transmitted by vampire bats. Euro Surveillance 10:E051110.3, 2005.

12. Lopez A, Miranda P, Tejada E, Fishbein DB. Outbreak of human rabies in the Peruvian jungle. Lancet 339:408-411, 1992.

13. Mayen F. Haematophagous bats in Brazil, their role in rabies transmission, impact on public health, livestock industry and alternatives to an indiscriminate reduction of bat population. Journal of Veterinary Medicine, Series B 50:469-472, 2003.

14. McMichael AJ, Woodruff RE, Hales S. Climate change and human health: present and future risks. Lancet 367:859-869, 2006.

15. Ministério da Saúde. Relatório de situação: Pernambuco. Ministério da Saúde, Brasília, 2006.

16. Noah DL, Drenzek CL, Smith JS, Krebs JW, Orciari L, Shaddock J, Sanderlin D, Whitfield S, Fekadu M, Olson JG, Rupprecht CE, Childs JE. Epidemiology of human rabies in the United States, 1980 to 1996. Annals of Internal Medicine 128:922-930, 1998.

17. Patz JA, Graczyk TK, Geller N, Vittor AY. Effects of environmental change on emerging parasitic diseases. International Journal for Parasitology 30:1395-1405, 2000.

18. Ramos MCD. Perfil psicossocial das pessoas agredidas por animais raivosos ou suspeitos de raiva na Grande São Paulo. Revista de Saúde Pública 12:26-34, 1978.

19. Rigo L, Honer MR. Human rabies prophylaxis in Campo Grande, Mato Grosso do Sul State, Brazil, 2002. Cadernos de Saúde Pública 21:1939-1945, 2005.

20. Rosa ES, Kotait I, Barbosa TF, Carrieri ML, Brandao PE, Pinheiro AS, Begot AL, Wada MY, Oliveira RC, Grisard EC, Ferreira M, Lima RJ, Montebello L, Medeiros DB, Sousa RC, Bensabath G, Carmo EH, Vasconcelos PF. Bat-transmitted human rabies outbreaks, Brazilian Amazon. Emerging Infectious Diseases 12:1197-1202, 2006.

21. Rupprecht CE, Smith JS, Fekadu M, Childs JE. The ascension of wildlife rabies: a cause for public health concern or intervention? Emerging Infectious Diseases 1:107-114, 1995.

22. Schneider MC, Belotto A, Adé MP, Leanes LF, Correa E, Tamayo H, Medina G, Rodrigues MJ. Epidemiologic situation of human rabies in Latin America in 2004. Epidemiological Bulletin 26:2-4, 2005.

23. Stantic-Pavlinic M. Public health concerns in bat rabies across Europe. Euro Surveillance 10:217-220, 2005.

24. Valderrama J, García I, Figueroa G, Rico E, Sanabria J, Rocha N, Parra E, Saad C, Paez A. Brotes de rabia humana transmitida por vampiros en los municipios de Bajo y Alto Baudó, departamento del Chocó, Colombia 2004-2005. Biomédica 26:387-396, 2006.

25. World Health Organization. WHO expert consultation on rabies, first report. World Health Organization Technical Report Series 931:1-88, 2005. 